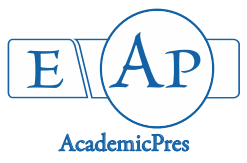

Badulescu A et al. (2020)

Notulae Scientia Biologicae 12(4):818-828

DOI: $10.15835 / 12410841$

Research Article

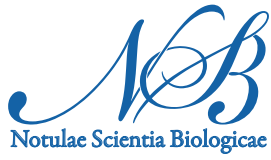

\title{
New varieties of tomato - morphological aspects and molecular characterisation with RAPD and SSR markers
}

\author{
Adriana BĂDULESCU, Carmen F. POPESCU*, \\ Anamaria M. DUMITRU, Dorin I. SUMEDREA
}

\author{
National Research and Development Institute for Biotechnology in Horticulture - Ștefăneşti, Calea Bucureşti - Piteşti, 37, Ştefăneşti, \\ Argeş, Romania; badulescuadriana18@yahoo.com; carm3n_popescu@yahoo.com (*corresponding author); \\ anamaria.ilina@yahoo.com;dsumedrea@yahoo.com
}

\begin{abstract}
This study presents the main morphological features and the first molecular investigations of four new tomato varieties (Solanum lycopersicum), aiming to obtain their complete characterisation. Evaluation with the standard descriptors for tomato revealed specific and distinct traits for each analysed variety. The molecular analyses for variety identification started with testing three methods for DNA extraction. With an optimized method, which doesn't need liquid nitrogen for plant tissue disruption, good quality DNA was obtained, in adequate quantities, and well preserved when stored at $-20^{\circ} \mathrm{C}$. To highlight the genetic differences among the analysed tomato varieties, nine RAPD primers and ten SSR primers were tested. Of these, the optimal amplification protocols for five RAPD primers and five SSR primers were established. The amplified products obtained with RAPD primers revealed an average number of bands per primer of 8.8 and a total rate of polymorphism of 59.1\%; with OPB10 primer was seen the highest number of DNA bands (11), and with OPA07 primer was registered the highest degree of genetic variability among the studied varieties (77.7\%). Two SSR markers (SSR 20 and SSR T107) amplified monomorphic banding patterns corresponding to 170 base pairs and 250 base pairs, respectively, for all varieties; with SSR T7, SSR T62, and SSR T70 primers were generated multiple amplification bands, with a different distribution of the bands into the agarose gel for each analysed tomato variety.
\end{abstract}

Keywords: description; genotypes; molecular markers; variability

\section{Introduction}

Tomato (Solanum lycopersicum L.) is one of the vegetable crops with the widest growing area in the world, appreciated not only for its fruit qualities, but also for its pharmaceutical and therapeutic importance. This plant represents an important study material for breeding and research programmes, and a very profitable crop for farmers. At present, more than 83,000 accessions are kept in plant collections and seed banks, which could cover the needs and desires of consumers in terms of shape, colour, size, taste and nutritional qualities of the fruits. 
Conventional tomato breeding has been developed to increase the diversity of the commercial fruit aspect (Cong et al., 2008; Rodriguez et al., 2011), the resistance/tolerance to abiotic or biotic stresses (Kochieva et al., 2002), or to obtain valuable plant material for construction of genetic linkage map of cultivated tomato varieties and wild tomato species (Rick, 1975; Tanksley et al., 1992; Frary et al., 2004).

Because cultivated tomatoes are autogamous plants and have been obtained by self-pollination, the great diversity of genotypes is mostly the result of inherited diversity from their wild relatives (Miller and Tanksley, 1990). Knowledge about this genetic diversity based on morphological, biochemical, and molecular data is essential for an efficient use of plant material for both germplasm seed bank collections and seed producers (Goncalves et al., 2009). Genetic seed purity and the variety identity are parameters that ensure agricultural productivity and food security. Thus, breeders, vegetable farmers and tomato derived product producers, could be the beneficiaries of a complete characterized plant material before to use it (Vishwanath et al., 2010; Vînătoru et al., 2016; Doltu et al., 2018).

The standard descriptors applied in accordance to internationally accepted rules for the coding, scoring, and recording, are currently used for the initial characterization of tomato phenotypes. The registered morphological aspects represent the result of complex interactions between genotype and growth environment and their evaluation strongly depends on curator experience. Since the morphological characterization does not provide accurate information necessary to distinguish different genotypes, further assessment of collected germplasms at the molecular level is required (Carmen de Vicente et al., 2006; Ferreira, 2006). In the last three decades, beside morphological descriptors and production parameters, molecular markers offered a huge amount of useful information regarding genetic diversity of tomato (Smulders et al., 1997; Chakravarthi and Naravaneni, 2006; Glaszmann et al., 2010), marker-trait associations to agronomic interest indicators (Parmar et al., 2013), molecular markers used in marker-assisted selection (Benor et al., 2008), study of genetic relationships among genotypes (Alam et al., 2012).

In this study are presented the distinct and characteristic morphological descriptors, and the main potential yield parameters for the first four tomato varieties released by the National Research and Development Institute for Biotechnology in Horticulture Ştefăneşti-Argeş. For a complete description were applied molecular methods with Random Amplified Polymorphic DNA (RAPD) and Simple Sequence Repeat (SSR) markers aiming to provide the first genetic information and the starting proofs about identity of these varieties.

\section{Materials and Methods}

\section{Plant material}

Four tomato cultivars (Solanum lycopersicum L.) created at The Research and Development Institute for Biotechnology in Horticulture Ştefăneşti-Argeş, and released in 2012 and 2013 were used in the present investigation (Figure 1): two varieties with determinate growth ('Argeş 11' and 'Argeş 20'), and two varieties with indeterminate growth ('Ştefăneşti 21' and 'Costate 22').

Morphological features were evaluated according to the international standards for tomato descriptors (Darwin et al., 2003). Four plants per variety were selected to be evaluated during three consecutively vegetative seasons and the main characters included: plant height $(\mathrm{cm})$, number of branches per plant, number of fruits per bunch, average fruit weight $(\mathrm{g})$ and yield per plant $(\mathrm{g})$.

The analysis of variance (ANOVA) for the morphological features related with yield/plant was carried out and statistic differences among varieties was analysed with Duncan test. The difference between the averages was evaluated using a significance level of $\mathrm{P} \leq 0.05$. 


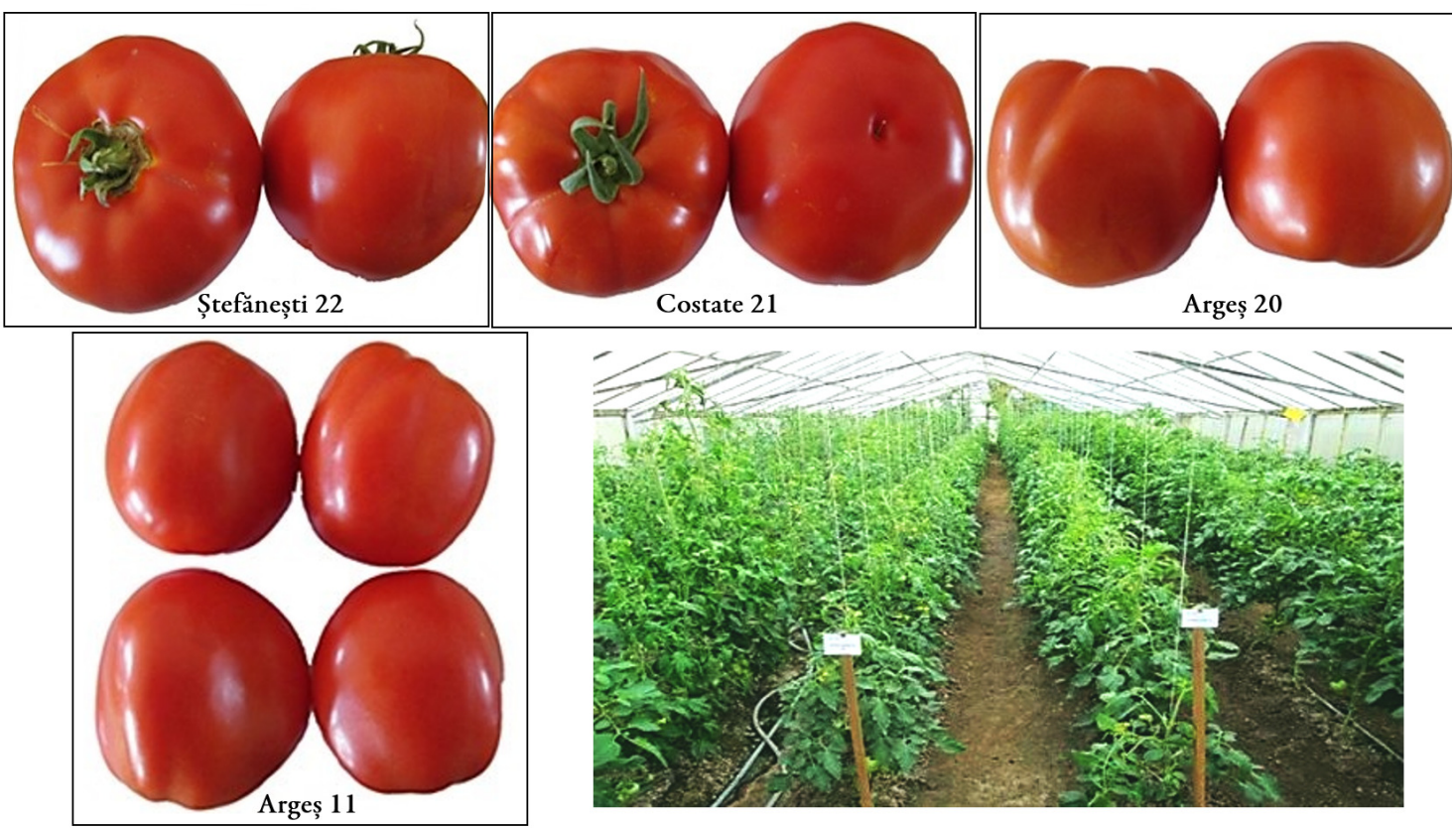

Figure 1. The greenhouse and the cultivars analyzed

\section{DNA extraction}

For DNA extraction were used fresh and healthy leaves in four replications, following three recommended protocols, each of them with some modifications regarding: the quantities of plant material, used reagents, speed, temperature and time of centrifugations. In the first method (Mamidala and Nanna, 2009), very simple and easy to follow, the small pieces of leaves were crushed with glass pistil against the tube walls. Instead of the lysis compounds recommended by Mamidala and Nanna (2009), we used: cationic detergent cetyl-trimethyl-ammonium bromide (CTAB) lysis buffer, plus 20\% sodium dodecyl sulfate (SDS), $0.2 \%$ mercaptoethanol, and sodium acetate. The final DNA extract was eluted in sterile nuclease free water.

The second method tested in our laboratory followed the protocol recommended by Ahmed et al. (2009), except of: adding the RNase after disrupting samples with lysis buffer and before the incubation, and eluting the final DNA extract in Qiagen elution buffer.

The third method applied for tomato young leaves used DNeasy Plant Kit and followed the protocol recommended by producer. With this method the leaves were ground in liquid nitrogen to fine powder.

\section{$D N A$ quality}

The quantity and quality of total DNA obtained by the three methods were verified with spectrophotometer BioPhotometer plus (Eppendorf) and by gel electrophoresis. After determining the amount of genomic DNA in each eluted solution, and their purity by the ratio absorbance A260/A280, all good DNA samples were stored at $-20{ }^{\circ} \mathrm{C}$. The gel for electrophoresis was prepared with $1.3 \%$ agarose in Trisacetate-EDTA (TAE) buffer and with $0.5 \% \mu \mathrm{l}$ of ethidium bromide for DNA staining. For electrophoretic migration were used $4 \mu \mathrm{l}$ DNA sample plus $4 \mu \mathrm{l}$ of $6 \times$ loading dye. The images of the gels were obtained under UV light and documented with Gene Flash System.

\section{RAPD markers, protocol for amplification}

Nine RAPD primers: OPA02, OPA05, OPA07, OPA12, OPB04, OPB10, OPC02, OPC08 and OPC18 (Kaneka Eurogentec, Belgium) were tested. For each total volume of $25 \mu$ l, at amplification were used: $4 \mu \mathrm{l}$ of 5x FirePol Master Mix (FirePol DNA polymerase, 5x reaction buffer, $12.5 \mathrm{mM} \mathrm{MgCl}, 1 \mathrm{mM} \mathrm{dNTPs}$ produced by Solis BioDyne, Estonia); $4 \mu \mathrm{l}$ of primer; $4 \mu \mathrm{l}$ DNA template; $13 \mu \mathrm{l}$ of nuclease free water. The 
amplifications were performed in Techne TC-512 Therman Cycler with the following programme of amplification: one cycle of initial denaturation of $3 \mathrm{~min}$ at $94^{\circ} \mathrm{C} ; 35$ cycles with $1 \mathrm{~min}$ at $94^{\circ} \mathrm{C}$ for denaturation, different time $\left(30 \mathrm{sec}\right.$, or $1 \mathrm{~min}$ ) at $32^{\circ} \mathrm{C}$, or $33^{\circ} \mathrm{C}$, or $35^{\circ} \mathrm{C}$ for primers annealing, and 2 min at $72{ }^{\circ} \mathrm{C}$ for elongation; final extension of $7 \mathrm{~min}$ at $72^{\circ} \mathrm{C}$, and then kept at $4^{\circ} \mathrm{C}$.

\section{SSR markers, protocol}

A set of ten SSR primers provided by Kaneka Eurogentec, Belgium was selected to be tested with the four tomato varieties: SSR9, SSR20, SSR74, SSR241, SSRX90770, SSR T7, SSR T57, SSR T62, SSR T70, SSR T107. For PCR reactions were used: $5 \mu \mathrm{l}$ of $5 \mathrm{x}$ FirePol Master Mix Ready to load (Solis BioDyne, Estonia), $3 \mu \mathrm{l}$ DNA template, $2 \mu \mathrm{l}$ of forward and $2 \mu \mathrm{l}$ reverse primer, and water to a total volume of $25 \mu \mathrm{l}$. In a Techne TC512 Therman Cycler were carried out the cycling amplifications as following: one cycle for initial denaturation $4 \mathrm{~min}$ at $94^{\circ} \mathrm{C} ; 35$ cycles with $1 \mathrm{~min}$ at $94^{\circ} \mathrm{C}, 1 \mathrm{~min}$ at $55^{\circ} \mathrm{C}$, or $58^{\circ} \mathrm{C}$ for primers annealing, and $2 \mathrm{~min}$ at 72 ${ }^{\circ} \mathrm{C}$ for elongation. The final extension of $7 \mathrm{~min}$ at $72{ }^{\circ} \mathrm{C}$, and then maintained at $4{ }^{\circ} \mathrm{C}$.

The amplification products with RAPD and SSR markers were visualized after horizontal electrophoresis in $2.0 \%$ or $3.0 \%$ agarose gel respectively, with TAE buffer, and stained with ethidium bromide. The gels were photographed with Gene Flash Syngene Bio Imaging system under UV light. GeneRuler of 100 bp DNA Ladder (Solis BioDyne) was used as a molecular weight marker.

\section{Scoring bands of RAPD products}

From repeatable tests, the clear bands, as amplified products, were considered as present or absent bands for each variety and each primer. Starting from the total number of alleles, certain parameters were calculated:

a) the percentage of polymorphism - was obtained by dividing the polymorphic bands by the total number of scored bands:

(Number of polymorphic bands / Number of total bands) x 100;

b) the genetic diversity index for each primer (Nei, 1973) using formula:

$H=1-\Sigma$ Pi2

where: $\mathrm{H}$ is genetic diversity index and $\mathrm{Pi}$ is pattern's frequency for each band

\section{Results and Discussion}

\section{Morphological characterization}

Beside their common characteristic for the skin fruit colour (red), the main differences among the four tomato varieties are presented in Table 1 . The observations performed three years consecutively confirmed the uniformity of the seeds and stability of the morphological features. The varieties are different from each other by: the general aspect of the plant at the stage of maturity, the aspect of leaves, the size and shape of fruits. According to our records made at the moment of maturity, the two tomato varieties with determinate growth displayed either drooping aspect of the leaves, large high rounded fruit, angular in cross-section ('Argeş 11') or leaves with standard shape and horizontal disposition, and produced large red-fruit with round shape in crosssection ('Argeş 20'). Between the two tomato varieties with indeterminate growth are obvious the differences in attitude of the leaves and the shape of fruits. These morphological characteristics were criteria for selection of tomato varieties with yield potential, important for vegetable producers.

The main descriptors and measurements related with tomato fruit production are presented in Table 2 . The mean values of plant height are specific for a certain type of growth, and are correlated with the average fruit weight. Our results are similar to those described by Akinfasoye et al., (2011), and showed that taller plants produce heavier fruits.

Analysing the yield/plant in parallel with the other parameters among the four tomato varieties, the measurements showed significant differences for the number of branches/plants, and no significant differences 
for the number of fruits developed per bunch. This could be the consequence of the fact that the yield potential of a variety depends on fruit load per bunch, type of growth and time duration for new flowers appearance and development. Beside these, from a breeder point of view, in selection and hybridization, are more suitable, with higher chance to obtain a new variety, those genotypes with distinct and constant characteristics, but having larger range of variability for certain features (Golani et al., 2007).

Table 1. Descriptors for the distinct morphological traits

\begin{tabular}{|c|c|c|c|c|c|}
\hline $\begin{array}{c}\text { Code descriptor } \\
\text { - } \\
\text { Variety } \\
\end{array}$ & $\begin{array}{l}7.1 .2 .1 \\
\text { Plant growth type }\end{array}$ & $\begin{array}{c}\quad 7.1 .2 .8 \\
\text { Leaf attitude }\end{array}$ & $\begin{array}{l}7.1 .2 .9 \\
\text { Leaf type }\end{array}$ & $\begin{array}{c}\quad 7.2 .2 .5 \\
\text { Fruit shape }\end{array}$ & $\begin{array}{c}\text { 7.2.2.29 } \\
\text { Fruit cross- } \\
\text { sectional shape }\end{array}$ \\
\hline 'Argeş 11' & $\begin{array}{c}2 \\
\text { Determinate } \\
\text { growth }\end{array}$ & $\begin{array}{c}7 \\
\text { Drooping }\end{array}$ & $\begin{array}{c}7 \\
\text { Other type } \\
\text { of leaf }\end{array}$ & $\begin{array}{c}4 \\
\text { High rounded }\end{array}$ & $\begin{array}{c}2 \\
\text { Angular }\end{array}$ \\
\hline 'Argeş 20' & $\begin{array}{c}2 \\
\text { Determinate } \\
\text { growth }\end{array}$ & $\begin{array}{c}5 \\
\text { Horizontal }\end{array}$ & $\begin{array}{c}3 \\
\text { Standard leaf }\end{array}$ & $\begin{array}{l}4 \\
\text { High rounded }\end{array}$ & $\begin{array}{c}1 \\
\text { Round }\end{array}$ \\
\hline 'Ştefăneşti 22' & $\begin{array}{c}4 \\
\text { Indeterminate } \\
\text { growth }\end{array}$ & $\begin{array}{c}5 \\
\text { Horizontal }\end{array}$ & $\begin{array}{c}5 \\
\text { Pimpinellifolium } \\
\text { leaf }\end{array}$ & $\begin{array}{c}3 \\
\text { Rounded }\end{array}$ & $\begin{array}{c}1 \\
\text { Round }\end{array}$ \\
\hline 'Costate 21' & $\begin{array}{c}4 \\
\text { Indeterminate } \\
\text { growth }\end{array}$ & $\begin{array}{c}3 \\
\text { Semi-erect }\end{array}$ & $\begin{array}{c}5 \\
\text { Pimpinellifolium } \\
\text { leaf }\end{array}$ & $\begin{array}{c}2 \\
\text { Slightly } \\
\text { flattened }\end{array}$ & $\begin{array}{c}3 \\
\text { Irregular }\end{array}$ \\
\hline
\end{tabular}

(vegetative descriptors 7.1. and fruit descriptors 7.2. with their scored registrations)

Table 2. Mean values for some important agronomic traits

\begin{tabular}{|c|c|c|c|c|c|}
\hline Variety & $\begin{array}{c}\text { Plant height } \\
(\mathrm{cm})\end{array}$ & $\begin{array}{c}\text { No. of } \\
\text { branches/plant }\end{array}$ & $\begin{array}{c}\text { No. of } \\
\text { fruits/bunch }\end{array}$ & $\begin{array}{c}\text { Average fruit } \\
\text { weight }(\mathrm{g})\end{array}$ & $\begin{array}{c}\text { Yield/plant } \\
(\mathrm{g})\end{array}$ \\
\hline 'Argeş 11' & $65.63 \mathrm{c}$ & $5.5 \mathrm{~b}$ & $3.1 \mathrm{~ns}$ & $180.6 \mathrm{~b}$ & $3,079.2 \mathrm{~d}$ \\
\hline 'Argeş 20' & $79.55 \mathrm{c}$ & $5.4 \mathrm{~b}$ & $3.6 \mathrm{~ns}$ & $220.0 \mathrm{a}$ & $4,276.8 \mathrm{c}$ \\
\hline 'Ştefăneşti 22' & $110.71 \mathrm{~b}$ & $7.1 \mathrm{a}$ & $4.1 \mathrm{~ns}$ & $190.4 \mathrm{~b}$ & $5,542.5 \mathrm{a}$ \\
\hline 'Costate 21' & $135.82 \mathrm{a}$ & $5.7 \mathrm{a}$ & $3.8 \mathrm{~ns}$ & $230.7 \mathrm{a}$ & $4,996.9 \mathrm{~b}$ \\
\hline Mean \pm SD & $97.9 \pm 31.5$ & $5.9 \pm 0.8$ & $3.65 \pm 0.42$ & $205.45 \pm 23.74$ & $4,473.85 \pm 1,064.5$ \\
\hline
\end{tabular}

In each column, figures followed by the same letter are not statistically different, based on the Duncan test $(\mathrm{P} \leq 0.05)$.

In our study, statistical analysis of data related to type of growth, number of branches per plant, fruit average weight and yield per plant showed significant differences among genotypes at the $5 \%$ level by Duncan's multiple range test. These morpho-agronomic characters differences are important to be known, registered and used, first of all for breeding aims, to enlarge the range of genotypes with as diverse characters as possible.

\section{Optimized protocol for DNA extraction}

For tomatoes (Solanum lycopersicum sp.), like for many other plant species, numerous methods for DNA extraction have been tested (Ahmed et al., 2009; Mamidala and Nanna, 2009; Dubey et al., 2017). For any investigation at the DNA level, the primary condition is to obtain a genomic DNA of sufficient quantity and of good quality. Extraction protocols generally require relatively large amounts of fresh plant material (5$10 \mathrm{~g}$ ) that is fragmented, or finely ground (Jobes et al., 1995; Cheng et al., 2003) to facilitate its subsequent digestion. Some methods start from spontaneously frozen plant material and crushed in liquid nitrogen (Sharma et al., 2003; Saravanan et al., 2014), and other methods, that start with small amounts of plant tissues, require special devices (Hill-Ambroz et al., 2002; Mogg and Bond, 2003), or use commercial DNA extraction kits, which ultimately leads to a high cost per sample. Our aim was to test different methods for DNA extraction 
from tomato plants, to optimize the protocols and to obtain stable and good quality DNA samples in order to use them in further molecular analyses.

The results obtained from assessments of DNA quantity and quality with spectrophotometer are summarized in Table 3 . Among the three methods tested in our laboratory, the $2^{\text {nd }}$ one (protocol published by Ahmed et al., 2009) proved to be the most effective, both in terms of the amount of extracted DNA and its quality. Thus, the concentration of DNA obtained from the four tomato varieties was on average of $69.47 \pm$ $23.53 \mathrm{ng} / \mu \mathrm{l}$, with $24.7 \%$ higher than in samples extracted with the $1^{\text {st }}$ method, and 4.6 times higher in comparison with Qiagen method.

Referring to the purity of the obtained DNA solutions, expressed as the ratio of absorbances at 260 and $280 \mathrm{~nm}$, the values between 1.6 and 2.0 are considered indicators for a good purity. Our results showed good or very good quality of DNA extracted by applying Ahmed et al. (2009) and Qiagen methods. With tomato plant material, the Qiagen Kit method was efficient for the purity of the eluted DNA, but the quantities of total DNA extracted were lower.

In our experiments, the method recommended by Mamidala and Nanna (2009) considered to be much simplified, efficient, cheap and fast, proved not to be good enough for DNA extraction from tomato varieties. The total DNA was obtained in low quantities and deteriorated rapidly due to impurities and RNA that were not removed entirely by the applied procedure. However, due to its simplicity and short working time, the method could be tried on several other species, genotypes, or plant material in early stages of development.

The spectrophotometric measurements of DNA samples stored for nine months at $-20{ }^{\circ} \mathrm{C}$, showed almost identical values, confirming the stability of the genetic material and the efficiency of extraction methods 2 and 3. Subsequently, the stored DNA proved to be suitable for PCR using SSR and RAPD markers.

The quality of the DNA obtained by the three methods was confirmed by electrophoresis. The DNA bands were visible and clear when verifying samples extracted with the second and the third methods (data not shown). The gel images of DNA samples obtained with the first method showed fragmented genomic DNA, as weak bands and whitish smears along migration lanes. As a result, only samples that meet the appropriate quality parameters were used further in molecular assays.

Table 3. The efficiency of methods tested for DNA extraction from leaves in four tomato varieties

\begin{tabular}{|c|c|c|c|c|c|c|}
\hline \multirow{2}{*}{$\begin{array}{c}\text { Method/ } \\
\text { Variety }\end{array}$} & \multicolumn{2}{|c|}{$\begin{array}{c}\text { Method 1 } \\
\text { modified }\end{array}$} & \multicolumn{2}{c|}{$\begin{array}{c}\text { Method 2 } \\
\text { Ahmed et al. (2009) modified }\end{array}$} & \multicolumn{2}{c|}{$\begin{array}{c}\text { Method 3 } \\
\text { DNeasy Plant Kit }\end{array}$} \\
\cline { 2 - 7 } & $\begin{array}{c}\text { DNA } \\
\text { conc. } \\
\text { (ng/ul) }\end{array}$ & $\begin{array}{c}\text { Purity of } \\
\text { DNA }\end{array}$ & $\begin{array}{c}\text { DNA } \\
\text { Anc. } \\
(\mathrm{ng} / \mathrm{ul})\end{array}$ & $\begin{array}{c}\text { Purity of } \\
\text { DNA } \\
\text { A 260/280 }\end{array}$ & $\begin{array}{c}\text { DNA } \\
\text { conc. } \\
(\mathrm{ng} / \mathrm{ul})\end{array}$ & $\begin{array}{c}\text { Purity of DNA } \\
\text { A 260/280 }\end{array}$ \\
\hline 'Argeş 11' & $36.9 \pm 2.54$ & $1.41 \pm 0.014$ & $68.33 \pm 30.54$ & $1.72 \pm 0.052$ & $115.05 \pm 4.3$ & $1.78 \pm 0.01$ \\
\hline 'Argeş 20' & $64.5 \pm 3.39$ & $1.46 \pm 0.021$ & $74.57 \pm 26.29$ & $1.74 \pm 0.067$ & $34.85 \pm 9.7$ & $1.52 \pm 0.03$ \\
\hline 'Ştefăneşti 22' & $73.4 \pm 2.21$ & $1.43 \pm 0.077$ & $75.54 \pm 20.09$ & $1.71 \pm 0.070$ & $12.35 \pm 2.7$ & $1.73 \pm 0.02$ \\
\hline 'Costate 21' & $47.9 \pm 10.34$ & $1.36 \pm 0.021$ & $61.81 \pm 18.11$ & $1.72 \pm 0.062$ & $17.61 \pm 3.5$ & $1.70 \pm 0.03$ \\
\hline Mean \pm SD & $55.7 \pm 15.76$ & $1.42 \pm 0.051$ & $69.47 \pm 23.53$ & $1.73 \pm 0.061$ & $14.97 \pm 3.71$ & $1.68 \pm 0.11$ \\
\hline
\end{tabular}

Our results are in accordance with those reported by Ahmed et al. (2009) and Qiagen Kit producer, and proved the reliability and suitability of these two methods for obtaining good quality of total DNA from tomato tested varieties.

\section{Genetic diversity with RAPD markers}

In the first stage of our study, we tested the RAPD markers, which have been widely used for proving genetic diversity in plants and has many advantages, such as: it is a simple, fast and low-cost method; requires small amounts of DNA; it does not need any information about target DNA sequence; it is effective for 
highlighting genetic polymorphism, even in populations with very low degree of variability, such as is $S$. lycopersicum (Abd El-Hady et al., 2010).

Out of the nine RAPD primers tested with DNA obtained from analysed tomato varieties, amplification products were obtained for five primers (Table 4). With these primers, 44 amplification bands with different distribution in the electrophoresis gel were visible, with the size of scorable bands ranging between 150 and $1000 \mathrm{bp}$. With OPB10 primer were scored the highest number of DNA bands (11 bands), while with OPA07 primer was obtained the highest degree of DNA polymorphism among the studied tomato varieties (77.7\%). Per total, with the five RAPD primers, were scored a total number of 26 different bands or polymorphic bands, which corresponded to an average level of polymorphism of $59.1 \%$.

Table 4. RAPD primers, size range of the detected bands, numbers of polymorphic bands and their genetic diversity index obtained with analysed tomato genotypes

\begin{tabular}{|c|c|c|c|c|c|}
\hline $\begin{array}{c}\text { Oligo name of the } \\
\text { primers }\end{array}$ & $\begin{array}{c}\text { Fragment } \\
\text { size (bp) }\end{array}$ & $\begin{array}{c}\text { Number of } \\
\text { amplified bands }\end{array}$ & $\begin{array}{c}\text { Number of } \\
\text { polymorphic } \\
\text { bands }\end{array}$ & $\begin{array}{c}\text { Rate of } \\
\text { polymorphism \% }\end{array}$ & $\begin{array}{c}\text { Genetic diversity } \\
\text { index }\end{array}$ \\
\hline OPA02 & $300-1000$ & 9 & 4 & 44.4 & 0.664 \\
\hline OPA05 & $300-800$ & 8 & 4 & 50.0 & 0.640 \\
\hline OPA07 & $250-900$ & 9 & 7 & 77.7 & 0.676 \\
\hline OPB10 & $200-900$ & 11 & 7 & 63.6 & 0.637 \\
\hline OPC02 & $150-700$ & 7 & 4 & 57.1 & 0.675 \\
\hline Total & - & 44 & 26 & - & - \\
\hline Average & & 8.8 & 5.2 & 59.1 & 0.658 \\
\hline
\end{tabular}

The genetic diversity index, as expression of the polymorphic information content, calculated for each RAPD primer, with an average value of 0.658 , proved that these five primers were informative. The same primers, or some of them, were shown to be appropriate to characterize the variability among tomato genotypes (Rajput et al., 2005; Tabassum et al., 2013) and the genetic diversity index values obtained by us were similar with those obtained by Sharifova et al. (2013).

\section{Genetic diversity with SSR markers}

Due to relatively narrow genetic diversity of the species Solanum lycopersicum (Alvarez et al., 2001), and intensive selection applied during domestication, identifying of molecular markers to highlight the genetic polymorphism into tomato genotypes seems to be difficult. At present, as in many other crop species, SSR markers are used to investigate genetic diversity of tomato varieties, essential for databases and to keep a complete record of accessions from tomato seed banks or field collections (He et al., 2003).

Microsatellite markers, or repeated simple sequence markers (SSRs), have been used in plant diversity analysis because: they are easily amplified by polymerase chain reaction (PCR), have a high level of allelic diversity at different loci, they are evenly distributed throughout the genome and in a different way from one genotype to another. The results of our investigations to find out which of the tested SSR markers are adequate to highlight the genetic diversity among the four tomato varieties proved to be reproducible with five primers, respectively: SSR 20, SSR T107, SSR T7, SSR T70 and SSR T62.

Characteristic for the primers SSR 20 and SSR T107 are the monomorphic bands, having molecular weights corresponding to 170 base pairs (SSR 20) and 250 base pairs, respectively (SSR T107), which means that the four varieties do not differ in terms of the distribution of the bands obtained after amplification with these primers (Figure 2).

With the primers SSR T7, SSR T62 and SSR T70 were obvious the differences in bands distribution for each variety. Multiple amplification bands were clearly visible, whose number, colour intensity and distribution in the gel differed from one variety to another, representing the certain proof of the genetic differences among the four tomato genotypes (Figure 3). 
Our results are similar to those obtained in other laboratories with tomato varieties (Saravanan et al., 2014), and reinforce the generally accepted view that SSR primers, well selected and used for amplification with appropriate programs, can generate monomorphic or polymorphic DNA amplified products (Diklesh et al., 2016). These DNA bands are specific to each analysed genotype and can be used in subsequent experiments for varieties identification.

To confirm the genetic uniformity of plant material used in tomato demonstrative fields, were performed amplifications with different DNA samples obtained from different extractions from the same variety. The identical appearance of the profiles obtained with SSR markers and with DNA samples from the same variety, but from different plants, was the proof of the uniformity of the seed material, and also showed that these five SSR markers are adequate to determine the genetic identity of analysed tomato genotypes.

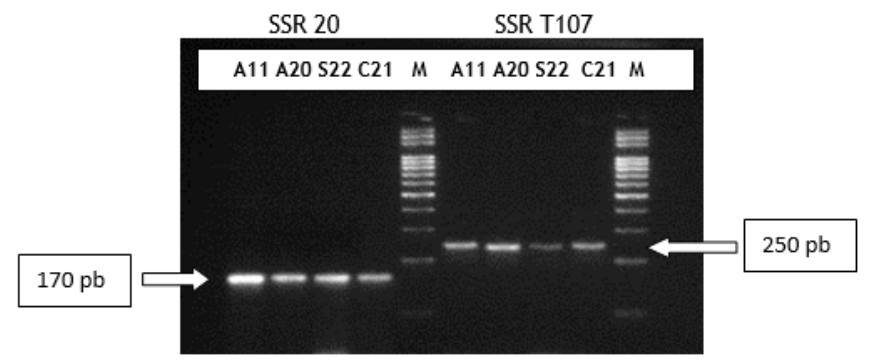

Figure 2. The monomorphic bands obtained with primers SSR 20 and SSR T107

Line $\mathrm{M}$ for DNA ladder followed by lines for amplified products obtained with DNA of tomato variety: 'Argeş 11' A11; 'Argeş 20' - A20; 'Ştefăneşti 22' - S22; 'Costate 21'- C21

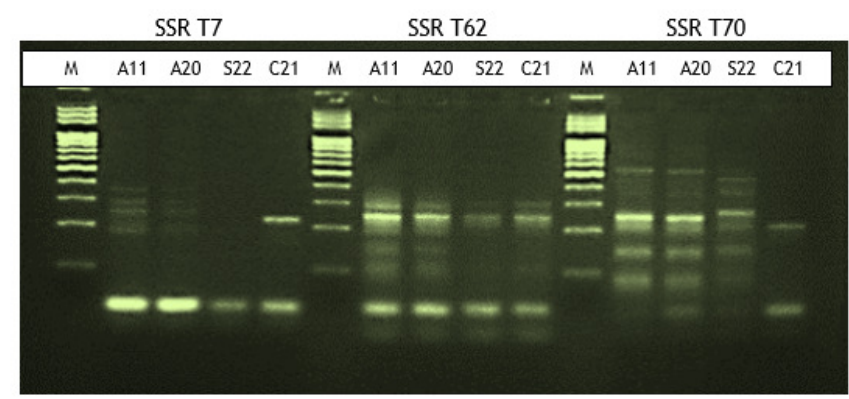

Figure 3. The amplification results obtained with primers SSR T7, SSR T62 and SSR T70

Line $M$ for DNA ladder followed by lines for amplified products obtained with DNA of tomato variety: 'Argeş 11' A11; 'Argeş 20' - A20; 'Ştefăneşti 22' - S22; 'Costate 21'- C21

\section{Conclusions}

This study presents the results of first attempt to analyse by molecular markers four new and valuable tomato varieties, two characterized by indeterminate growth ('Ştefăneşti 21' and 'Costate 22') and two by determinate growth ('Argeş 11' and 'Argeş 20'). Aiming to optimize the DNA extraction method and obtaining of good and very good quantities and qualities of the genetic material from the tomato varieties, were tested three protocols. Among these, the method recommended by Ahmed et al. (2009) has proven to be the most effective, both quantitatively and qualitatively. This method, which does not require liquid nitrogen for plant tissue grinding or expensive chemical compounds for extraction, was very efficient for all tested tomato varieties and the results were reproducible. Moreover, the checks of the quantity and quality by spectrophotometric measurements of the DNA samples stored at $-20{ }^{\circ} \mathrm{C}$ for nine months, showed their maintenance at the same level as at the moment of extraction. 
For a complete description, beside the morphological aspect of the plants, the molecular markers are widely used for assessing the uniformity of planting material for the new approved varieties and to prove their genetic diversity at the molecular level. From all the primers tested in our laboratory, five primers RAPD and five primers SSR, were efficient in assessing the four tomato genotypes and give us valuable information about genetic differences among them.

With a higher number of genotypes and more markers tested, will be possible to obtain relevant information regarding genetic richness of Romanian tomato genotypes maintained in gene banks, to find out the genetic structure and genetic distance of the local and cultivated varieties and also to develop markerassisted selection tools useful for breeding programmes.

\section{Authors' Contributions}

$A B$ and CFP: conceived and designed the experiments; $A B, C F P$ and AMD: methodology; DIS: formal analysis; $\mathrm{AB}, \mathrm{CFP}, \mathrm{AMD}$ and DIS: investigation; $\mathrm{AB}, \mathrm{CFP}$ and $\mathrm{AMD}$ : data curation; $\mathrm{CFP}$ : writing-review and editing; $\mathrm{AB}$ : visualization; DIS: supervision; $\mathrm{CFP}$ : project administration; $\mathrm{CFP}$ and $\mathrm{AB}$ : funding acquisition. All authors read and approved the final manuscript.

\section{Acknowledgements}

The authors are thankful to the Ministry of Agriculture and Rural Development for providing financial support for ADER 7.2.6. Research Project, through which was carried out this work and were obtained the described results.

\section{Conflict of Interests}

The authors declare that there are no conflicts of interest related to this article.

\section{References}

Abd El-Hady EA A, Haiba AAA, Abd El-Hamid NR, Rizkalla AA (2010). Phylogenetic diversity and relationships of some tomato varieties by electrophoretic protein and RAPD analysis. Journal of American Science 6(11):434441.

Ahmed I, Islam M, Arshad W, Mannan A, Ahmad W, Mirza B (2009). High-quality plant DNA extraction for PCR: an easy approach. Journal of Applied Genetics 50(2):105-107. https://doi.org/10.1007/BF03195661

Akinfasoye JA, Ogunniyan DJ, Ajayi EO (2011). Phenotypic relationship among agronomic characters of commercial tomato (Lycopersicum esculentum) hybrids. American-Eurasian Journal of Agronomy 4 (1):17-22.

Alam SkS, Ishrat E, Zaman MY, Habib MA (2012). Comparative karyotype and RAPD analysis for characterizing three varieties of Lycopersicon esculentum Mill. Bangladesh Journal of Botany 41(2):149-154. https://doi.org/10.3329/bjb.v41i2.13439

Alvarez AE, van de Wie CCM, Smulders MJM (2001). Use of microsatellites to evaluate genetic diversity and species relationships in the genus Lycopersicon. Theoretical and Applied Genetics 103:1283-1292. https://doi.org/10.1007/s001220100662

Benor S, Zhang M, Wang Z, Zhang H (2008). Assessment of genetic variation in tomato (Solanum lycopersicum L.) inbred lines using SSR molecular markers. Journal of Genetics and Genomics 35:373-379. https://doi.org/10.1016/S1673-8527(08)60054-5 
Botstein D, White RL, Skalnick MH, Davies RW (1980). Construction of a genetic linkage map in man using restriction fragment length polymorphism. American Journal of Human Genetics 32:314-331.

Carmen de Vicente M, Felix AG, Engels J, Ramanatha VR (2006). Genetic characterization and its use in decision making for the conservation of crop germplasm. In: Ruane J, Sonnino A (Eds.), The role of biotechnology in exploring and protecting agricultural genetic resources. Food and Agriculture Organization of the United Nations, Rome, Italy pp 128-138.

Chakravarthi B K, Naravaneni R (2006). SSR marker-based DNA fingerprinting and diversity study in rice (Oryza sativa. L). African Journal of Biotechnology 5:684-688.

Cheng YJ, Guo WW, Yi HL, Pang XM, Deng X (2003). An efficient protocol for genomic DNA extraction from citrus species. Plant Molecular Biology Reporter 21:177a-177g.

Cong B, Barrero L, Tanksley DS (2008). Regulatory change in YABBY-like transcription factor led to evolution of extreme fruit size during tomato domestication. Nature Genetics 40(6):800-804. https://doi.org/10.1038/ng.144

Darwin SC, Knapp S, Peralta IE (2003). Taxonomy of tomatoes in the Galapagos Islands: Native and introduced species of Solanum section Lycopersicon (Solanaceae). Systematics and Biodiversity 12:29-53. https://doi.org/10.1017/S1477200003001026

Diklesh K, Neeraj S, Vikrant KS, Dhananjay S, Girish C (2016). Assessment of genetic variation in tomato (Solanum lycopersicum L.) genotypes using SSR molecular markers. Ecology, Environment and Conservation 22:S317S325. https://doi.org/10.1016/S1673-8527(08)60054-5

Doltu M, Sora D, Nescșu M (2018). Technological aspects concerning growing of some Romanian tomato lines in greenhouse. Journal of Horticulture, Forestry and Biotechnology 22(1):58-62.

Dubey SM, Kumar S, Antre SH, Ramanjini Gowda PH (2017). Comparative study of high-quality genomic DNA extraction protocols in rice and tomato crops. International Journal of Current Microbiology and Applied Sciences 6(11):2763-2772. https://doi.org/10.20546/ijcmas.2017.611.327

Frary A, Fulton TM, Zamir D, Tanksley SD (2004). Advanced backcross QTL analysis of a Lycopersicon esculentum $x$ L. pennellii cross and identification of possible orthologs in the Solanaceae. Theoretical and Applied Genetics 108(3):485-496. https://doi.org/10.1007/s00122-003-1422-X

Glaszmann JC, Kilian B, Upadhyaya HD, Varshney RK (2010). Accessing genetic diversity for crop improvement. Current Opinion in Plant Biology 13:167-173. https://doi.org/10.1016/j.pbi.2010.01.004

Golani IJ, Mehta DR, Purohit VL, Pandya HM, Kanzariya MV (2007). Genetic variability, correlation and path coefficient studies in tomato. Indian Journal of Agriculture and Research 41(2):146-149.

Goncalves LS, Rodrigues R, do Amaral AT, Karasawa M (2009). Heirloom tomato gene bank: assessing genetic divergence based on morphological, agronomic and molecular data using a Ward-modified location model. Genetics and Molecular Research 8:364-374. https://doi.org/10.4238/vol8-1gmr549

He C, Poysa V, Yu K. (2003). Development and characterization of simple sequence repeat (SSR) markers and their use in determining relationships among Lycopersicon esculentum cultivars. Theoretical and Applied Genetics 106:363-373. https://doi.org/10.1007/s00122-002-1076-0

Hill-Ambroz KL, Brown-Guedira GL, Fellers JP (2002). Modified rapid DNA extraction protocol for high throughput microsatellite analysis in wheat. Crop Science 42:2088-2091. https://doi.org/10.2135/cropsci2002.2088

Jobes DV, Hurley DL, Thien LB (1995). Plant DNA isolation: A method to efficiently remove polyphenolics, polysaccharides and RNA. Taxon 44:349-386.

Kochieva EZ, Ryzhova NN, Khrapalova IA and Phukhaskyi VA (2002). Using RAPD for estimating genetic polymorphism in and phylogenetic relationships among species of the genus Lycopersicon(Tourn) Mill. Russian Journal of Genetics 38(9):1104-1108.

Mamidala P, Nanna RS (2009). A simple and rapid method for DNA extraction from leaves of tomato, tabaco and rape seed. Journal of Phytology 1(6):388-390.

Miller JC, Tanksley SD (1990). RFLP analysis of phylogenetic relationships and genetic variation in the genus Lycopersicon. Theoretical and Applied Genetics 80(4):437-448. https://doi.org/10.1007/BF00226743

Mogg RJ, Bond JM (2003). A cheap, reliable and rapid method of extracting high-quality DNA from plants. Molecular Ecology Notes 3:666-668. https://doi.org/10.1046/j.1471-8286.2003.00548.x

Nei M (1973). Analysis of gene diversity in subdivided population. Proceedings of the National Academy of Sciences of the United States of America 70:3321-3323. https://doi.org/10.1073/pnas.70.12.3321 
Parmar P, Sudhir A, Preethi R, Bhaumik D, Panchal KK, Bhagwathi R, Subramanian APA, Kathiria KB (2013). Identification of a SSR marker (TOM-144) linked to Fusarium wilt resistance in Solanum lycopersicum. American Journal of Molecular Biology 3:241-247. https://doi.org/10.4236/ajmb.2013.34031

Rajput SG, Wable KJ, Sharma KM, Kubde PD, Mulay SA (2006). Reproducibility testing of RAPD and SSR markers in tomato. African Journal of Biotechnology 5(2):108-112. https://doi.org/10.5897/AJB2006.000-5016

Rick CM (1975). The tomato. In: King RC (Eds). Handbook of genetics. New York Plenum Press, 2:247-280.

Rodriguez GR, Muños S, Anderson C, Sim SC, Michel A, Causse M, ... van der Knaap E (2011). Distribution of SUN, $O V A T E, L C$, and $F A S$ in the tomato germplasm and the relationship to fruit shape diversity. Plant Physiology 156:275-285. https://doi.org/10.1104/pp.110.167577

Saravanan KR, Rajaram R, Renganathan P (2014). Studies on genetic diversity using SSR marker associated traits in tomato genotypes (Lycopersicum esculentum L.). European Journal of Biotechnology and Bioscience 1(5):2629.

Sharifova S, Mehdiyeva S, Theodorikas K, Roubos K (2013). Assessment of genetic diversity in cultivated tomato (Solanum lycopersicum L.) genotypes using RAPD primers. Journal of Horticultural Research 21(1):83-89. https://doi.org/10.2478/johr-2013-0012

Sharma R, John SJ, Damgaard DM, McAllister TA (2003). Extraction of PCR-quality plant and microbial DNA from total rumen contents. BioTechniques 34:92-97. https://doi.org/10.2144/03341st06

Smulders MJM, Bredemeijer G, Rus-Kortekaas W, Arens P (1997). Use of short microsatellite from database sequences to generate polymorphisms among Lycopersicon esculentum cultivars and accessions of other Lycopersicon species. Theoretical and Applied Genetics 94:264-272. https://doi.org/10.1007/s001220050409

Tabassum N, Sony SK, Bhajan SK., Islam MN (2013). Analysis of genetic diversity in eleven tomato (Lycopersicon esculentum Mill.) varieties using RAPD markers. Plant Tissue Culture and Biotechnology 23(1):49-57. https://doi.org/10.3329/ptcb.v23i1.15559

Tanksley SD, Ganal MW, Prince JP, de Vicente MC, Bonierbale MW, Broun P, ... Martin GB (1992). High density molecular linkage maps of the tomato and potato genomes. Genetics 132:1141-1160.

Vishwanath K, Prasanna KPR, Pallvi H M, Rajendra P, Ramegowda S, Devaraju P (2010). Identification of tomato (Lycopersicon esculentum) varieties through total soluble seed proteins. Research Journal of Agricultural Sciences 2(1):08-12.

Vînătoru C, Zamfir B, Bratu C, Lăcătuș V, Cârstea L (2016). New processing tomato varieties obtained at V.R.D.S. Buzău. Scientific Papers. Series B. Horticulture LX:155-160.
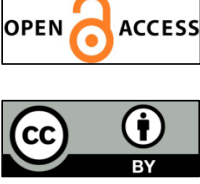

The journal offers free, immediate, and unrestricted access to peer-reviewed research and scholarly work. Users are allowed to read, download, copy, distribute, print, search, or link to the full texts of the articles, or use them for any other lawful purpose, without asking prior permission from the publisher or the author.

License - Articles published in Notulae Scientia Biologicae are Open-Access, distributed under the terms and conditions of the Creative Commons Attribution (CC BY 4.0) License.

(c) Articles by the authors; SHST, Cluj-Napoca, Romania. The journal allows the author(s) to hold the copyright/to retain publishing rights without restriction. 